\title{
Use of substrates and hydrogel to produce desert rose seedlings
}

\author{
João Luiz Lopes Monteiro Neto ${ }^{1 *}$, Wellington Farias Araújo ${ }^{2}$, Sonicley da Silva Maia ${ }^{1}$, Iasmin Kele Amancio Costa da Silva ${ }^{2}$, \\ Edvan Alves Chagas ${ }^{3}$, Jorge Zamir Erazo Amaya ${ }^{4}$, Carlos Abanto-Rodriguez ${ }^{5}$
}

\begin{abstract}
Adenium obesum (Forssk.) Roem. \& Schult., widely known as desert rose, has attracted interest for its esthetic characteristics, which are influenced by the process of seedling production. Using two consecutive experiments installed fully at random, the study aimed at assessing the use of different substrates and hydrogel to produce desert rose seedlings in a protected environment. First, eleven substrates were tested, prepared as follows: OrganoAmazon ${ }^{\circledR}$; PuroHumus ${ }^{\circledR}$; soil; rice husk in natura; carbonized rice husk, sawdust and cattle manure. Then, three substrates were tested (S1 - OrganoAmazon ${ }^{\circledR}+$ PuroHumus $^{\circledR} ;$ S2 - OrganoAmazon ${ }^{\circledR}$ + PuroHumus $^{\circledR}+$ rice husk in natura and S3 - OrganoAmazon ${ }^{\circledR}+$ PuroHumus $^{\circledR}+$ carbonized rice husk) associated to four hydrogel levels: 0 (daily irrigation), 1, 2 and $3 \mathrm{~g} \mathrm{~L}^{-1}$ (irrigated on alternate days). Growth variables and quality index of seedlings were assessed. Six substrates (all of them without addition of sawdust and where used in mix) were grouped as those the promoted appropriate growth of seedlings, with height, number of leaves, collar diameter, root length and aerial part biomass superior to $6.5 \mathrm{~cm} ; 13 ; 12 \mathrm{~mm} ; 7.5 \mathrm{~cm}$ and $0.45 \mathrm{~g}$, respectively. The substrate composed of OrganoAmazon ${ }^{\circledR}+$ PuroHumus $^{\circledR}(1: 1 \mathrm{v} / \mathrm{v})$, when irrigated daily, was the one that favored most the production of quality seedlings. The use of hydrogel in substrates with shifts of irrigation on alternate days did not favor the production of desert rose seedlings.
\end{abstract}

Keywords: Adenium obesum, irrigation, quality seedlings, OrganoAmazon ${ }^{\circledR}$, sawdust.

\section{Resumo}

Uso de substratos e hidrogel na produção de mudas de rosa-do-deserto

Adenium obesum (Forssk.) Roem. \& Schult., amplamente conhecida como rosa-do-deserto, tem despertado interesse pelas suas características estéticas que são influenciadas pelo processo de produção de mudas. Com isso, por meio de dois experimentos consecutivos instalados inteiramente ao acaso, objetivou-se avaliar o uso de diferentes substratos e hidrogel na produção de mudas de rosa-do-deserto, em ambiente protegido. Primeiramente, foram testados onze substratos confeccionados a partir de: OrganoAmazon $^{\circledR}$; PuroHumus ${ }^{\circledR}$; solo; casca-de-arroz in natura; casca-de-arroz carbonizada, serragem e esterco bovino. Em seguida, foram testados três substratos (S1 - OrganoAmazon ${ }^{\circledR}+$ PuroHumus $^{\circledR}$; S2 - OrganoAmazon ${ }^{\circledR}+$ PuroHumus $^{\circledR}+$ casca-dearroz in natura e S3 - OrganoAmazon ${ }^{\circledR}+$ PuroHumus $^{\circledR}+$ casca-de-arroz carbonizada) associados a quatro níveis de hidrogel: 0 (irrigação diária), 1, 2 e $3 \mathrm{~g} \mathrm{~L}^{-1}$ (irrigados em dias alternados). Foram avaliadas variáveis de crescimento e índices de qualidade das mudas. Seis substratos (todos sem adição de serragem e quando usados em mistura) agruparam-se como os que promoveram o adequado crescimento das mudas, com: altura, número de folhas, diâmetro do colo, comprimento radicular e biomassa da parte aérea superiores a $6,5 \mathrm{~cm} ; 13 ; 12 \mathrm{~mm} ; 7,5 \mathrm{~cm}$ e $0,45 \mathrm{~g}$, respectivamente. O substrato composto por OrganoAmazon ${ }^{\circledR}+$ PuroHumus $^{\circledR}$ $(1: 1 \mathrm{v} / \mathrm{v})$, quando irrigado diariamente, foi o que mais favoreceu a produção de mudas de qualidade. A utilização de hidrogel em substratos com turnos de rega realizados em dias alternados não favoreceu a produção das mudas de rosa-do-deserto.

Palavras-chave: Adenium obesum, irrigação, mudas de qualidade, OrganoAmazon ${ }^{\circledR}$, serragem.

\footnotetext{
${ }^{1}$ Universidade Federal de Roraima (UFRR), Boa Vista-RR, Brazil. "Corresponding author: joao.monteiro.neto@hotmail.com

${ }^{2}$ Universidade Federal de Roraima (UFRR), Departamento de Solos e Engenharia, Boa Vista-RR, Brazil.

${ }^{3}$ Empresa Brasileira de Pesquisa Agropecuária (EMBRAPA RORAIMA), Boa Vista-RR, Brazil.

${ }^{4}$ Universidad Nacional de Agricultura, Faculdad de Ciencias Agrarias, Catacamas-OL, Honduras.

${ }^{5}$ Instituto de Investigaciones de la Amazonía Peruana (IIAP), Yarinacocha-UC, Peru, e Programa de Pós-graduação em Biodiversidade e Biotecnologia da Amazônia Legal (REDE BIONORTE), UFRR, Boa Vista-RR, Brazil.
} 


\section{Introduction}

Desert rose [Adenium obesum (Forssk.) Roem. \& Schult.], ornamental plant of the Apocynaceae family, has attracted attention for presenting exotic and sculptural characteristics like: thick branches, large stem base, peculiar sizes and exuberant flowering, which makes them highly desirable for use in gardens and other ornamentation areas (Colombo et al., 2018a). However, these characteristics are only expressed or improved when the plants are subject to optimal management conditions. In this regard, the first important phase of this process is seedling production, for the plants performance in definitive location depends on it.

In the stage of production of desert rose seedlings, one of the essential factors for vigorous initial development of the plants is the choice of an efficient substrate (Alves et al., 2018). According to Campanharo et al. (2006), the substrate should ensure mechanical support to the root system, ensure water and nutrient supply and provide oxygen and $\mathrm{CO}_{2}$ transport across the seedlings roots and the external environment. It is worth mentioning that, in addition to the premises required for a good substrate, substrates should be made with materials locally available or near the production location, since they may represent significant increase in production costs, particularly when commercially used or acquired (Monteiro Neto et al., 2016). The desert rose, for being included in the group of species economically profitable only during the last decade, still counts on incipient information on the production system, and on recommendation of substrates for production of seedlings (Colombo et al., 2018b).

In addition to the choice of an appropriate substrate, water management in this phase of cultivation is determinant in the seedling production feasibility, due to the high costs and excessive use of water. In this context, agricultural hydrogels, presented as alternative for efficient water use, have been used as conditioners of soil due to their capacity to retain water and nutrient to the plants (Klein and Klein, 2015), a fact that makes possible to reduce the number of irrigations and loss of nutrients, resulting in economy in the process of seedling production.

In a review study on the use of agricultural hydrogels in Brazilian agriculture, Monteiro Neto et al. (2017) reported the use of several commercial products in the production of different species, indicating important results as to the use of these polymers to obtain quality seedlings. On the other hand, no study with grounded information on ornamental species like desert rose was identified, a fact that renders difficult decision making with regard to its use in productive and experimental scale in this field of agriculture.

Therefore, establishing a system for production of seedlings that offers significant utilization of water conditions and materials available to make substrates in each region is vital to make feasible the obtention of quality seedlings of any species. In this context, this work aimed at assessing different substrates and the use of hydrogel to produce desert rose seedling in a protected environment.

\section{Material and Methods}

Two consecutive experiments, presented separately in this work, were conducted under arch type greenhouse covered with low density polyethylene (LDPE) and laterally protected with $50 \%$ shading black sombrite ${ }^{\circledR}$. The area is located in the mesoregion in the North of Roraima state, in the following coordinates: $2^{\circ} 52^{\prime} 18^{\prime \prime} \mathrm{N}, 60^{\circ} 42^{\prime} 34^{\prime \prime} \mathrm{W}$; $90 \mathrm{~m}$ altitude, whose climatic classification is Aw type, with annual rainfall averages, temperature and humidity of $1,678 \mathrm{~mm}, 27.4^{\circ} \mathrm{C}$ and $70 \%$, respectively.

They were both installed as random design, with experimental units comprising seedlings planted in 220 $\mathrm{cm}^{3}$ plastic recipients, perforated in the bottom and filled in their vase with type 0 gravel $(4.8 \mathrm{~mm}$ to $9.5 \mathrm{~mm})$ to drain water and contain substrate loss.

Before sowing, the seeds were soaked in water for thirty minutes for full hydration. Sowing occurred with three seeds per recipient, at $0.5 \mathrm{~cm}$ of depth. Twenty five days after emergence (25 DAE), only one plant per recipient was left, and those with visible defects or outside the standards observed in the other plants were discarded.

Sixty days after sowing (DAS), for each experiment, the following variables were assessed: plant height $(\mathrm{PH})$, number of leaves (NL), collar diameter (CD), root length (RL), aerial part dry mass (APDM) and root dry mass (RDM). Based on these variables, the seedlings growth quality indices were also determined: plant height/collar diameter ratio (PH/CD) and Dickson quality index (DQI), determined by: $\mathrm{DQI}=\mathrm{RDM} /(\mathrm{PH} / \mathrm{CD}+\mathrm{APDM} / \mathrm{RDM})$.

Plant height $(\mathrm{PH})$ and root length (RL) were determined with millimeter ruler, with measurements from the collar to the insertion of the last leaf and from the collar to the end of the root, respectively. The number of leaves (NL) was measured by counting the fully expanded leaves. Collar diameter (CD), expressed in millimeters ( $\mathrm{mm})$, was determined with a precision electronic caliper. The seedlings biomass (APDM and RDM) was determined after their submission to the greenhouse with forced air circulation at $65{ }^{\circ} \mathrm{C}$ for 96 hours, using a precision analytical balance.

\section{Substrates for production of desert rose seedlings}

Eleven compositions of substrates were tested from August to October 2017: S1 - OrganoAmazon ${ }^{\circledR}$; S2 - OrganoAmazon ${ }^{\circledR}+$ PuroHumus $^{\circledR}(1: 1 \mathrm{v} / \mathrm{v}) ; \mathrm{S} 3$ OrganoAmazon $^{\circledR}+$ PuroHumus $^{\circledR}+$ soil $(1: 1: 1 \mathrm{v} / \mathrm{v}) ; \mathrm{S} 4$ - OrganoAmazon ${ }^{\circledR}+$ PuroHumus $^{\circledR}+$ rice husk in natura $(1: 1: 1 \mathrm{v} / \mathrm{v}) ;$ S5 - OrganoAmazon ${ }^{\circledR}+$ PuroHumus $^{\circledR}+$ carbonized rice husk $(1: 1: 1 \mathrm{v} / \mathrm{v})$; S6 - OrganoAmazon ${ }^{\circledR}+$ PuroHumus $^{\circledR}+$ sawdust $(1: 1: 1 \mathrm{v} / \mathrm{v}) ; \mathrm{S} 7$ - OrganoAmazon ${ }^{\circledR}$ + PuroHumus $^{\circledR}+$ soil + carbonized rice husk $(1: 1: 1: 1 \mathrm{v} / \mathrm{v})$; S8 - OrganoAmazon ${ }^{\circledR}+$ PuroHumus $^{\circledR}+$ soil + sawdust $(1: 1: 1: 1 \mathrm{v} / \mathrm{v}) ;$ S9 - Soil; S10 - OrganoAmazon ${ }^{\circledR}+$ Soil $(1: 1$ $\mathrm{v} / \mathrm{v})$; and S11 - cattle manure + carbonized rice husk + sawdust $(1: 1: 1 \mathrm{v} / \mathrm{v})$, both with four repetitions and three plants per experimental unit. 
PuroHumus $^{\circledR}$ and OrganoAmazon ${ }^{\circledR}$ compounds were acquired in the specialized local commerce in Boa VistaRR. The soil used was classified as dystrophic yellow oxisol, and was extracted close to the experimental area at a depth of $0-20 \mathrm{~cm}$ and sieved with a $2.0 \mathrm{~mm}$ sieve to remove larger particles. Sawdust, from the region native woods, was acquired from a sawmill in the municipality of Rorainópolis-RR, and treated with current water for a week. Rice husk was carbonized in UFRR's Agrarian Sciences Center. Cattle manure, from animals extensively raised, was sieved in $2.0 \mathrm{~mm}$ sieve and daily watered until cure.

All components of substrates analyzed (OrganoAmazon $^{\circledR}$, PuroHumus ${ }^{\circledR}$, soil, cattle manure, rice husk in natura and carbonized, except for sawdust) were used by Monteiro Neto et al. (2016). Chemical and physical analyses of substrates were extracted from this work, and were used as reference for discussion of the results here obtained, since some substrates, like S1, S2 and S5, were also tested in the mentioned study.

During the experiment, seedlings were irrigated on a daily basis by means of a micro-sprinkler system in two shifts (morning and afternoon). Where necessary, invasive plants were manually removed, and there was no need of phytosanitary control of plagues and diseases. After obtention of data from the variables analyzed and observation of normal distribution, variance analyses and Scott-Knott test at 5\% of probability were performed in order to group the best treatments, using software Sisvar (Ferreira, 2011).

\section{Use of hydrogel in different substrate to produce desert rose seedlings}

During October and December 2017, three substrates were assessed, [S1 - OrganoAmazon ${ }^{\circledR}+$ PuroHumus $^{\circledR}(1: 1$ v/v); S2 - OrganoAmazon ${ }^{\circledR}+$ PuroHumus $^{\circledR}+$ rice husk in natura $(1: 1: 1 \mathrm{v} / \mathrm{v})$ and S3 - OrganoAmazon ${ }^{\circledR}+$ PuroHumus $^{\circledR}$ + carbonized rice husk $(1: 1: 1 \mathrm{v} / \mathrm{v})]$ associated to four hydrogel levels [0 (daily irrigation), 1, 2 and $3 \mathrm{~g}$ per liter of substrate], with $3 \times 4$ factorial scheme, four repetitions and three plants per experimental unit. These three substrates were also used in the first experiment.

For hydrogel handling, Hidroterragel ${ }^{\circledR}$ polymer was used acquired in the specialized commerce. It was weighted and directly incorporated to substrates at the established doses. After mixing, homogenization and sowing were performed, and finally hydration of substrates by irrigating until saturation.

Seeking a better observation of the results expressed by hydrogel, substrates with the different amounts of this polymer (1,2 and $3 \mathrm{~g}$ per liter of substrate) were irrigated in alternate days along the experimental period, except for the two weeks after sowing, the period required for plants to present approximately $3 \mathrm{~cm}$ of height with daily irrigations. After this period, watering shifts were adopted, on alternate days established for hydrogel levels.

Data from variables analyzed were submitted to variance analysis and, with observation of significant effect through $\mathrm{F}$ test, averages were compared with Tukey test $t 5 \%$ of probability, both with assistance of statistical program Sisvar (Ferreira, 2011).

\section{Results and Discussion}

\section{Substrates for production of desert rose seedlings}

In all growth and quality variables analyzed, significant effects were identified $(\mathrm{p} \leq 0.01)$ across the substrates tested (Table 1), indicating that the compositions formulated promote different responses in the production of desert rose seedlings.

Table 1. Variance analysis for: plant height (PH), number of leaves (NL), collar diameter (CD), root length (RL), aerial part dry mass (APDM), root dry mass (RDM), PH/CD ratio and Dickson Quality Index of desert rose seedlings produced in different substrates.

\begin{tabular}{|c|c|c|c|c|c|}
\hline \multirow{2}{*}{ VS } & DF & \multicolumn{4}{|c|}{ Mean squares } \\
\hline Substrate & 10 & PH & NL & CD & RL \\
\hline Waste & 33 & $21.6^{* *}$ & $102.6^{* *}$ & $45.3 * *$ & $8.9 * *$ \\
\hline CV (\%) & & 0.9 & 5.05 & 2.78 & 0.87 \\
\hline & & 16.9 & 17.7 & 13.2 & 11.6 \\
\hline Substrate & 10 & APDM & RDM & PH/CD & DQI \\
\hline Waste & 33 & $0.2 * *$ & $0.1 * *$ & $4.00 * *$ & $0.003376^{* *}$ \\
\hline CV (\%) & & 0.01 & 0.01 & 0.53 & 0.000158 \\
\hline
\end{tabular}

** significant at $1 \%$ probability by $\mathrm{F}$ test. VS: variation sources. DF: degrees of freedom. 
In general, six substrates were grouped with potential for production of desert rose seedlings: S2 - OrganoAmazon ${ }^{\circledR}$ + PuroHumus $^{\circledR} ;$ S3 - OrganoAmazon ${ }^{\circledR}+$ PuroHumus $^{\circledR}+$ soil; S4 - OrganoAmazon ${ }^{\circledR}+$ PuroHumus $^{\circledR}+$ rice husk in natura; S5 - OrganoAmazon ${ }^{\circledR}+$ PuroHumus $^{\circledR}+$ carbonized rice husk; S7 - OrganoAmazon ${ }^{\circledR}+$ PuroHumus $^{\circledR}+$ soil + carbonized rice husk and S10 - OrganoAmazon ${ }^{\circledR}+$ soil.

For plant height $(\mathrm{PH})$, number of leaves $(\mathrm{NL})$, collar diameter (CD) and root length (RL), three substrates (S3, S5 and S7) proved to be efficient for significant increase in all these variables, distinct from the others. However, when analyzed separately, distinct groups of substrates are identified as to the efficiency in each variable studied (Table 2), indicating that there was direct relation among the plant parts and the components used to prepare the tested compounds for desert rose seedlings.

Table 2. Plant height (PH), number of leaves (NL), collar diameter (CD), root length (RL), of desert rose seedlings produced in different substrates.

\begin{tabular}{|c|c|c|c|c|}
\hline Substrates & PH (cm) & NL & CD (mm) & RL (cm) \\
\hline S1- OrgA ${ }^{\circledR}$ & $3.63 \mathrm{~b}^{*}$ & $9.25 \mathrm{c}$ & $6.76 \mathrm{c}$ & $4.65 \mathrm{c}$ \\
\hline $\mathrm{S} 2-\operatorname{Org} \mathrm{A}^{\circledR}+\mathrm{PH}^{\circledR}$ & $7.43 \mathrm{a}$ & $16.10 \mathrm{~b}$ & $14.10 \mathrm{a}$ & $7.52 \mathrm{a}$ \\
\hline S3- Org $A^{\circledR}+$ PH $^{\circledR}+$ Soil & $7.73 \mathrm{a}$ & $19.68 \mathrm{a}$ & $15.55 \mathrm{a}$ & $8.18 \mathrm{a}$ \\
\hline $\mathrm{S} 4-\mathrm{OrgA}^{\circledR}+\mathrm{PH}^{\circledR}+\mathrm{RH}$ in & $6.57 \mathrm{a}$ & $13.92 \mathrm{~b}$ & $15.30 \mathrm{a}$ & $9.21 \mathrm{a}$ \\
\hline $\mathrm{S} 5-\operatorname{Org} \mathrm{A}^{\circledR}+\mathrm{PH}^{\circledR}+\mathrm{CRH}$ & $8.14 \mathrm{a}$ & $18.08 \mathrm{a}$ & $16.05 \mathrm{a}$ & $8.98 \mathrm{a}$ \\
\hline S6- Org $A^{\circledR}+$ PH $^{\circledR}+$ Sawdust & $3.44 \mathrm{~b}$ & $7.00 \mathrm{~d}$ & $10.21 \mathrm{~b}$ & $8.56 \mathrm{a}$ \\
\hline S7- OrgA ${ }^{\circledR}+\mathrm{PH}^{\circledR}+$ Soil $+\mathrm{CRH}$ & $7.63 \mathrm{a}$ & $17.63 \mathrm{a}$ & $15.36 \mathrm{a}$ & $9.87 \mathrm{a}$ \\
\hline S8- OrgA $A^{\circledR}+\mathrm{PH}^{\circledR}+$ Soil + Sawdust & $3.28 \mathrm{~b}$ & $6.63 \mathrm{~d}$ & $9.94 \mathrm{~b}$ & $7.89 \mathrm{a}$ \\
\hline S9- Soil & $3.51 \mathrm{~b}$ & $10.75 \mathrm{c}$ & $12.64 \mathrm{a}$ & $8.92 \mathrm{a}$ \\
\hline S10- OrgA $A^{\circledR}+$ Soil & $8.01 \mathrm{a}$ & $15.13 \mathrm{~b}$ & $15.53 \mathrm{a}$ & $8.43 \mathrm{a}$ \\
\hline S11- Cattle manure $+\mathrm{CRH}+$ Sawdust & $2.39 \mathrm{~b}$ & $5.58 \mathrm{~d}$ & $8.12 \mathrm{c}$ & $6.13 \mathrm{~b}$ \\
\hline
\end{tabular}

*Means followed by the same letter in the column do not differ from each other by the Scott-Knott test $(\mathrm{p} \leq 0.05)$.

Captions: OrgA ${ }^{\circledR}$ : OrganoAmazon ${ }^{\circledR} ; \mathrm{PH}^{\circledR}$ : PuroHumus ${ }^{\circledR} ; \mathrm{RH}$ in: rice husk in natura; $\mathrm{CRH}$ : carbonized rice husk

For $\mathrm{PH}$, the two substrate groups identified are associated to the use of OrganoAmazon ${ }^{\circledR}$ mixed with another tested material, except with sawdust, and compounds S2, S3, S4, S5, S7 and S10 (all from the mixture of OrganoAmazon ${ }^{\circledR}$ with material other than sawdust) were outstanding when compared to the others ( $\mathrm{S} 1, \mathrm{~S} 6, \mathrm{~S} 8, \mathrm{~S} 9$ and S11), which, in their turn, were not different from each other (Table 2). The same substrates that promoted more increase in seedlings height (S2, S3, S4, S5, S7 and S10) also provided increment in $\mathrm{CD}$ values, indicating that they were directly associated to the development of desert rose seedlings' aerial part.

According to Monteiro Neto et al. (2018), plant height $(\mathrm{PH})$ is a variable used as quality standard for seedlings produced in nursery, however, it should be combined with collar diameter (CD), thus constituting one of the most important parameters of vegetal growth. This indicates that, though the highlighted substrates present more increment of PH and CD, they still can't be defined as promoters of quality growth with the isolated quantification of these variables alone.
With regard to NL, variable associated to photosynthetic processes and energy and photo-assimilated production, three substrates were grouped as the most outstanding (S3, S5 and S7), both producing seedlings superior to $17 \mathrm{~cm}$. Differently from what was observed for NL, nine substrates were grouped with higher values of root length (RL), and S1 (OrganoAmazon ${ }^{\circledR}$ ) and S11 (cattle manure + $\mathrm{CAC}+$ sawdust) presented the lowest rates of root growth (Table 2).

Substrates that contributed to numerical increase in all growth variables (PH, CD, NL and RL), therefore, also presented the highest biomass values. These results indicate that APDM has direct relation to $\mathrm{PH}$, and the same substrates were grouped with the highest values in two variables (Tables 2 and 3), evidencing that the use of sawdust in substrates significantly affects the increment of biomass in desert rose seedlings' aerial parts. For RDM, on the other hand, substrates S3, S4, S5, S7 and S10 were grouped with the highest values, when compared to the others (Table 3 ). 
Table 3. Aerial part dry mass (APDM), root dry mass (RDM), PH/CD ratio and Dickson Quality Index of desert rose seedlings produced in different substrates.

\begin{tabular}{|c|c|c|c|c|}
\hline Substrates & APDM & RDM & $\mathrm{PH} / \mathrm{CD}$ & DQI \\
\hline $\mathrm{S} 1-\operatorname{Org} \mathrm{A}^{\circledR}$ & $0.04 b^{*}$ & $0.0098 \mathrm{~d}$ & $53.1 \mathrm{a}$ & $0.54 \mathrm{c}$ \\
\hline $\mathrm{S} 2-\operatorname{Org} \mathrm{A}^{\circledR}+\mathrm{PH}^{\circledR}$ & $0.51 \mathrm{a}$ & $0.0950 \mathrm{~b}$ & $53.9 \mathrm{a}$ & $0.57 \mathrm{a}$ \\
\hline S3- OrgA $A^{\circledR}+$ PH $^{\circledR}+$ Soil & $0.59 \mathrm{a}$ & $0.1600 \mathrm{a}$ & $50.1 \mathrm{a}$ & $0.87 \mathrm{a}$ \\
\hline $\mathrm{S} 4-\operatorname{Org} \mathrm{A}^{\circledR}+\mathrm{PH}^{\circledR}+\mathrm{RH}$ in & $0.48 \mathrm{a}$ & $0.1300 \mathrm{a}$ & $43.1 \mathrm{a}$ & $0.75 \mathrm{a}$ \\
\hline S5- OrgA ${ }^{\circledR}+\mathrm{PH}^{\circledR}+\mathrm{CRH}$ & $0.63 \mathrm{a}$ & $0.1200 \mathrm{~b}$ & $50.6 \mathrm{a}$ & $0.72 \mathrm{a}$ \\
\hline S6- OrgA $\mathrm{A}^{\circledR}+\mathrm{PH}^{\circledR}+$ Sawdust & $0.18 \mathrm{~b}$ & $0.0510 \mathrm{c}$ & $33.6 \mathrm{~b}$ & $0.33 \mathrm{~b}$ \\
\hline S7- OrgA $A^{\circledR}+\mathrm{PH}^{\circledR}+$ Soil $+\mathrm{CRH}$ & $0.65 \mathrm{a}$ & $0.1500 \mathrm{a}$ & $49.8 \mathrm{a}$ & $0.86 \mathrm{a}$ \\
\hline S8- Org $A^{\circledR}+\mathrm{PH}^{\circledR}+$ Soil + Sawdust & $0.15 \mathrm{~b}$ & $0.0430 \mathrm{c}$ & $33.2 \mathrm{~b}$ & $0.28 \mathrm{~b}$ \\
\hline S9- Soil & $0.15 \mathrm{~b}$ & $0.0750 \mathrm{c}$ & $28.5 \mathrm{~b}$ & $0.47 \mathrm{~b}$ \\
\hline S10- OrgA ${ }^{\circledR}+$ Soil & $0.58 \mathrm{a}$ & $0.1300 \mathrm{a}$ & $51.8 \mathrm{a}$ & $0.75 \mathrm{a}$ \\
\hline S11- Cattle manure $+\mathrm{CRH}+$ Sawdust & $0.06 \mathrm{~b}$ & $0.0200 \mathrm{~d}$ & $30.5 \mathrm{~b}$ & $0.14 \mathrm{c}$ \\
\hline
\end{tabular}

* Means followed by the same letter in the column do not differ from each other by the Scott-Knott test $(\mathrm{p} \leq 0.05)$.

Captions: OrgA ${ }^{\circledR}$ : OrganoAmazon ${ }^{\circledR} ; \mathrm{PH}^{\circledR}$ : PuroHumus ${ }^{\circledR} ; \mathrm{RH}$ in: rice husk in natura; CRH: carbonized rice husk.

In general, two specific substrates, $\mathrm{S} 1\left(\right.$ OrganoAmazon $\left.^{\circledR}\right)$ and S9 (Soil), and those that had sawdust in their composition (S6, S8 and S11) were not efficient for production. The low values found with OrganoAmazon ${ }^{\circledR}$, when used separately (S1), may be associated to the low nutritional allocation offered by this substrate (Monteiro Neto et al., 2016), which suggests that the process of production of desert rose seedlings requires substrates with high nutritional content.

Similar results as to the low productive efficiency of OrganoAmazon ${ }^{\circledR}$ are reported for bell pepper seedlings growth (Monteiro Neto et al., 2016) and for two tomato varieties (Monteiro Neto et al., 2018). The authors confirm the lower nutritional contents in this substrate compared to the others, a fact that may also have occurred with the substrate containing only soil. Though OrganoAmazon ${ }^{\circledR}$ is used to produce greeneries, its use to produce ornamental species seedlings is still rare, a fact that renders difficult the discussion with compared literature. However, as indicated by the manufacturer, it is a substrate prepared with the mixture of several components: cattle, horse, chicken, and lamb manure, sawdust, aged and carbonized rice straw, peat, sugarcane bagasse, grass trims, branches and foliage.

For sawdust, according to Andrade et al. (2015), a possible phytotoxicity of this material may have been the reason for the low performance found in substrates S6, S8 and S11 (Tables 2 and 3). Considering that it was not possible to identify the origin of the sawdust used, because the sawmill that provided the material uses different forestry species, it is suggested that before using it to produce seedlings, the species and treatments used in their processing should be identified before acquiring this specific material. Likewise, we suggest that the process to treat sawdust must be really efficient, because inefficiency to eliminate substances toxic to the plants may cause losses to the plants growth, a fact that possibly occurred with substrates containing this material.

As to seedlings' growth quality indices, two groups of substrates are identified in $\mathrm{PH} / \mathrm{CD}$ ratio, those with the lowest values (S1, S2, S3, S4, S5, S7 and S10) and those that presented collar diameter growth proportional to aerial part length (S6, S7, S9, S11) (Table 3). According to Rodrigues et al. (2010), this variable indicates appropriate development of seedlings, since plant height increase is proportionally followed by collar thickness. This relation, according to Gomes et al. (2002), is determinant to the seedlings' survival estimate, where, the higher the CD value against $\mathrm{PH}$, the higher will be the chances of survival of seedlings in the field, that is, lower values in HP/CD ratio indicate better development conditions of plants.

An isolated interpretation of $\mathrm{HP} / \mathrm{CD}$ ratio would induce to affirm that substrates S9, S11, S8 and S6 would promote better conditions to the development desert rose seedlings. However, when we observe the other variables analyzed, like NL and plants biomass, we can notice that this relation was not a determinant parameter for the qualitative development of desert rose seedlings, considering the low growth of seedlings submitted to these substrates (Table 3 ).

DQI, for including morphological variables of height, collar diameter and biomass, proved to be efficient in determining of compounds that favored more the seedlings qualitative growth, since the substrates that promoted higher development of all variables analyzed (S3, S5 and S7) also presented the highest DQI (Table 3). The substrates that promoted satisfactory results for all variables, except for NL (S2, S4 and S10), also behaved efficiently as to DQI, that is, this index separated the groups of more efficient substrates from those with low increment in the development of desert rose seedlings (S1, S6, S8, S9 and S11). 
The results found here provide technical-scientific support to the use of substrates to produce desert rose seedlings under the experiment conditions, however, it is worth mentioning that more detailed studies on the phases after that of seedling production are necessary, since the species presents large genetic variability and high cost for stand implantation, a fact that justifies the tests suggested to produce plants of this species in commercial scale.
Use of hydrogel in different substrates for production of desert rose seedlings

Among all variables analyzed, the interaction of the factors assessed was significant only for RDM. Substrates proved to be different from each other in variables $\mathrm{PH}$, NL, APDM, PH/CD and DQI. Irrigation management with hydrogel, on the other hand, presented variation only for HP, CD, APDM and quality indices (HP/ DQI) (Table 4).

Table 4. Variance analysis for: plant height (PH), number of leaves (NL), collar diameter (CD), root length (RL), aerial part dry mass (APDM), root dry mass (RDM), PH/CD ratio and Dickson Quality Index of desert rose seedlings produced in different levels of hydrogel and substrates.

\begin{tabular}{|c|c|c|c|c|c|}
\hline VS & DF & \multicolumn{4}{|c|}{ Mean squares } \\
\hline & & PH & NL & CD & RL \\
\hline Hydrogel (H) & 3 & $20.39^{* *}$ & $10.47^{\mathrm{NS}}$ & $81.01^{* *}$ & $0.70^{\mathrm{NS}}$ \\
\hline Substrate (S) & 2 & $53.42^{* *}$ & $72.84^{* *}$ & $0.72^{\mathrm{NS}}$ & $4.61^{\mathrm{NS}}$ \\
\hline H x S & 6 & $0.71^{\mathrm{NS}}$ & $11.97^{\mathrm{NS}}$ & $4.80^{\mathrm{NS}}$ & $2.00^{\mathrm{NS}}$ \\
\hline Waste & 36 & 0.84 & 5.94 & 7.38 & 2.88 \\
\hline CV (\%) & & 11.48 & 17.93 & 22.25 & 19.80 \\
\hline Hydrogel (H) & 3 & APDM & RDM & PH/CD & DQI \\
\hline Substrate (S) & 2 & $0.32^{* *}$ & $0.001^{*}$ & $5.64 *$ & $0.00078^{* *}$ \\
\hline H x S & 6 & $0.14^{* *}$ & $0.004^{*}$ & $45.47^{* *}$ & $0.0015^{* *}$ \\
\hline Waste & 36 & $0.01^{\mathrm{NS}}$ & $0.001^{*}$ & $1.84^{\mathrm{NS}}$ & $0.00016^{\mathrm{NS}}$ \\
\hline CV (\%) & & 0.01 & 0.0002 & 1.38 & 0.00008 \\
\hline
\end{tabular}

$\mathrm{NS}, * *^{* *}$, non significant, significant at $5 \%$ and significant at $1 \%$, respectively, by $\mathrm{F}$ test. VS: variation sources. DF: degrees of freedom.

The isolated effect of hydrogel use is presented in Table 5 , where, in general, daily irrigation promoted the best conditions for desert rose seedlings growth, being superior in all quality and quantity variables analyzed. These results indicate that desert rose species presents high demand of water, and that the hydrogel doses tested were not sufficient to retain enough amounts of water for the good development of the seedlings.

These affirmations are verified by Colombo et al. (2018b) who concluded that desert rose seedlings must be kept in substrates with capacity of water retention superior to $60 \%$ of irrigation for their growth not to be compromised. These conditions, in fact, were not provided to the plants dues to the watering shifts adopted, suggesting that the use of hydrogel in different doses was not sufficient to keep the minimum required moisture for the seedlings growth.

Associated to that, the local meteorological conditions, already recorded at the experiment location (Monteiro Neto et al., 2018), favor more evapotranspiration chiefly due to high temperatures (Shimada et al., 2017), which must have increased water restriction to plants, which, according to Taiz and Zeiger (2013), affect all their development phases, limiting the growth of important physical characters like size, number of leaves, stem and branches, and may, therefore, make the plant more susceptible to attack by several phytophagous insects (Tiago Neto et al., 2017). 
Table 5. Plant height (PH), collar diameter (CD), aerial part dry mass (APDM), PH/CD ratio and Dickson Quality Index (DQI) of desert rose seedlings produced in different levels of hydrogel.

\begin{tabular}{|c|c|c|c|c|c|c|}
\hline Treatments & PH & CD & APDM & PH/CD & DQI \\
\hline Daily irrigation & $9.83 \mathrm{a}^{*}$ & $16.03 \mathrm{a}$ & $0.79 \mathrm{a}$ & $6.43 \mathrm{ab}$ & $0.06 \mathrm{a}$ \\
\hline Hydrogel $\left(1 \mathrm{~g} \mathrm{~L}^{-1}\right)$ & $6.89 \mathrm{~b}$ & $11.63 \mathrm{~b}$ & $0.48 \mathrm{~b}$ & $5.98 \mathrm{~b}$ & $0.05 \mathrm{ab}$ \\
\hline Hydrogel $\left(2 \mathrm{~g} \mathrm{~L}^{-1}\right)$ & $7.28 \mathrm{~b}$ & $10.36 \mathrm{~b}$ & $0.46 \mathrm{~b}$ & $7.08 \mathrm{ab}$ & $0.04 \mathrm{c}$ \\
\hline Hydrogel $\left(3 \mathrm{~g} \mathrm{~L}^{-1}\right)$ & $7.87 \mathrm{~b}$ & $10.82 \mathrm{~b}$ & $0.50 \mathrm{~b}$ & $7.53 \mathrm{a}$ & $0.04 \mathrm{c}$ \\
\hline
\end{tabular}

* Means followed by the same letter in the column do not differ from each other by the Tukey test $(\mathrm{p} \leq 0.05)$

With regard to the isolated effect of substrates, the compound containing OrganoAmazon ${ }^{\circledR}$ and PuroHumus ${ }^{\circledR}$ (S1) was the one that promoted most the development of desert rose seedlings, and was superior in all variables analyzed, including quality indices (Table 6).

Comparing the statistical analyses made in both experiments, the substrates tested here were grouped by the Scott-Knott test as being three of the most significantly efficient (first experiment), however, when Tukey test was applied for comparison of treatments (second experiment), $\mathrm{S} 1$ showed to be, in isolation, the one that favored most the seedlings development, suggesting that this substrate can be used to produce higher quality seedlings. This substrate, once the low yield of seedlings produced with OrganoAmazon ${ }^{\circledR}$ was identified when assessed in isolation, was effectively favored by the presence of PuroHumus ${ }^{\circledR}$, which has possibly incremented significant nutritional allocation to the seedlings, a fact observed in the work of assessment of five compounds for production of bell pepper seedlings conducted by Monteiro Neto et al. (2016), who found high levels of total N, P, K, Ca, Mg, S, B, Cu, $\mathrm{Mn}, \mathrm{Zn}, \mathrm{F}$ and organic $\mathrm{C}$, in addition to low density and lower $\mathrm{C} / \mathrm{N}$ ratio, a fact that justifies the favoring of $\mathrm{S} 1$ (OrganoAmazon $^{\circledR}+$ PuroHumus $^{\circledR}$ ) for production of desert rose seedlings.

PuroHumus $^{\circledR}$, produced from vermicompositing, is characterized by higher stabilization of organic wastes that, through earthworm digestive tract, suffer enzymatic reactions and are quickly converted into large amount of humic substances (HS), which are organic compounds with high persistence in substrate (Baldotto and Baldotto, 2014), and that presented efficient responses in the process of seedling production (Baldoto et al., 2015; Borcioni et al., 2016; Santos et al., 2018).

For RDM, only variable that presented response to the interaction between substrates and level of hydrogel, the substrates assessed proved to be statistically equal when irrigated on a daily basis and when mixed to hydrogel in the amount of $2 \mathrm{~g} \mathrm{~L}^{-1}$. For the other levels of hydrogel, substrate S2 (OrganoAmazon ${ }^{\circledR}+$ PuroHumus $^{\circledR}+$ rice husk in natura) was the one that influenced most root biomass increase. When levels of hydrogel are analyzed inside each substrate, differences are observed only in $\mathrm{S} 2$, where the use of $2 \mathrm{~g} \mathrm{~L}^{-1}$ of hydrogel provided the lowest RDM value (Table 7).

Table 6. Plant height (PH), number of leaves (NL), aerial part dry mass (APDM), PH/CD ratio and Dickson Quality Index (DQI) of desert rose seedlings produced in different levels of substrates.

\begin{tabular}{|c|c|c|c|c|c|c|}
\hline Treatments & PH & NL & APDM & PH/CD & DQI \\
\hline S1 - Org. + PH & $9.95 \mathrm{a}^{*}$ & $15.90 \mathrm{a}$ & $0.65 \mathrm{a}$ & $8.50 \mathrm{a}$ & $0.04 \mathrm{a}$ \\
\hline S2 - Org. + PH + RH in & $6.35 \mathrm{c}$ & $11.69 \mathrm{~b}$ & $0.47 \mathrm{~b}$ & $5.14 \mathrm{c}$ & $0.06 \mathrm{~b}$ \\
\hline S3 - Org. + PH + CRH & $7.61 \mathrm{~b}$ & $13.90 \mathrm{~b}$ & $0.51 \mathrm{~b}$ & $6.62 \mathrm{~b}$ & $0.04 \mathrm{~b}$ \\
\hline
\end{tabular}

\footnotetext{
* Means followed by the same letter in the column do not differ from each other by the Tukey test $(\mathrm{p} \leq 0.05)$

Captions: S1 (OrganoAmazon ${ }^{\circledR}+$ PuroHumus $\left.{ }^{\circledR}\right)$; S2 (OrganoAmazon ${ }^{\circledR}+$ PuroHumus ${ }^{\circledR}+$ rice husk in natura); S3 (OrganoAmazon ${ }^{\circledR}+$ PuroHumus ${ }^{\circledR}$ + carbonized rice husk).
} 
Table 7. Root dry mass (RDM) of desert rose seedlings produced under different substrates and levels of hydrogel.

\begin{tabular}{|c|l|l|l|l|}
\hline Treatments & S1 & S2 & S3 & Mean \\
\hline Daily irrigation & $0.0795 \mathrm{Aa}$ & $0.0955 \mathrm{ABa}$ & $0.0735 \mathrm{Aa}$ & 0.0828 \\
\hline $\mathrm{H}\left(1 \mathrm{~g} \mathrm{~L}^{-1}\right)$ & $0.0610 \mathrm{Ab}$ & $0.1138 \mathrm{Aa}$ & $0.0740 \mathrm{Ab}$ & 0.0829 \\
\hline $\mathrm{H}\left(2 \mathrm{~g} \mathrm{~L}^{-1}\right)$ & $0.0633 \mathrm{Aa}$ & $0.0715 \mathrm{Ba}$ & $0.0703 \mathrm{Aa}$ & 0.0683 \\
\hline $\mathrm{H}\left(3 \mathrm{~g} \mathrm{~L}^{-1}\right)$ & $0.0603 \mathrm{Ab}$ & $0.1013 \mathrm{Aa}$ & $0.0543 \mathrm{Ab}$ & 0.0719 \\
\hline Mean & 0.066 & 0.0955 & 0.068 & \\
\hline
\end{tabular}

Means followed by the same letter, capital letters in columns and lower cases in lines do not differ from each other by the Tukey test ( $\mathrm{p} \leq 0.05$ ) Captions: S1 (OrganoAmazon ${ }^{\circledR}+$ PuroHumus $\left.{ }^{\circledR}\right)$; S2 (OrganoAmazon ${ }^{\circledR}+$ PuroHumus ${ }^{\circledR}+$ rice husk in natura); S3 (OrganoAmazon ${ }^{\circledR}+$ PuroHumus ${ }^{\circledR}$ + carbonized rice husk).

Important results for desert rose seedlings production are raised in this work, chiefly with regard to hydrogel low performance in the increment of variables analyzed. However, it should be emphasized that this polymer low efficient, as observed in the present study, may be associated to the water management adopted in the experiment, which suggests new works with its use in variations of treatments that provide more amplitude for possible positive results of this material, as already reported in different works on the production of seedlings in Brazilian agriculture (Monteiro Neto et al., 2017).

\section{Conclusions}

The compound formulated with OrganoAmazon ${ }^{\circledR}$ + PuroHumus $^{\circledR}(1: 1 \mathrm{v} / \mathrm{v})$ promotes obtention of quality seedlings of desert rose (Adenium obesum) under protected environment. The use of hydrogel associated to substrates irrigated on alternate days does not favor the production of desert rose seedlings.

\section{Acknowledgement}

The authors thank to CNPq (National Council for Scientific and Technological Development) for the financial support via Universal Edital (Universal Public Notice) process 408673/20168, and CAPES (Coordination for Improvement of Higher Education Personnel) for the granting of scholarships.

\section{Author Contribution}

J.L.L.M.N. ${ }^{0000-0002-8300-5928}$ planning, statistical analysis, data interpretation and manuscript writing. W.F.A. ${ }^{0000-0001-6002-1223}$ guidance, planning and manuscript review. S.S.M. ${ }^{000-0003-0167-3218}$ experiment conduction and manuscript writing. I.K.A.C.S. ${ }^{0000-0001-}$ 5072-8022 experiment conduction. E.A.C. ${ }^{0000-0001-8604-7819}$ guidance and manuscript review. J.Z.E.A. ${ }^{0000-0002-4226-0973}$ statistical analysis and manuscript writing. C.A.R. ${ }^{0000-0001-7956-5482}$ experiment conduction and interpretation of statistical data.

\section{References}

ALVES, G.A.C.; HOSHINO, R.T.; BERTONCELLI, D.J.; SUZUKI, A.B.P; COLOMBO, R.C.; FARIA, R.T. Substrates and fertilizations in the initial growth of the desert rose. Ornamental Horticulture, v.24, n.1, p.19-27, 2018. DOI: http://dx.doi.org/10.14295/oh.v24i1.998

ANDRADE, F.R.; PETTER, F.A.; JUNIOR, B.H.M.; GONÇALVES, L.G.V.; SCHOSSLER, T.R.; NÓBREGA, J.C.A. Formulação de substratos alternativos na formação inicial de mudas de ingazeiro. Scientia Agrária Paranaenses, v.14, n.4, p.234-239, 2015. DOI: http:// dx.doi.org/10.1818/sap.v14i4.9769

BALDOTTO, M.A.; BALDOTO, L.E.B. Ácidos húmicos. Revista Ceres, v.61, Suplemento, p.856-881, 2014. DOI: http://dx.doi.org/10.1590/0034-737x201461000011

BALDOTO, L.E.B.; BALDOTTO, M.A.; SIMÕES, M.P.; OLIVEIRA, R.R.; MARTINEZ, H.E.P., VENEGAS, V.H.A. Acclimation of croton and hibiscus seedlings in response to the application of indobultiric acid and humic acid for rooting. Revista Ceres, v.62, n.3, p.284-293, 2015. DOI: http://dx.doi.org/10.1590/0034-737X201562030008

BORCIONI, E.; MÓGOR, A.F.; PINTO, F. Aplicação de ácido fúlvico em mudas influenciando o crescimento radicular e produtividade de alface americana. Revista Ciência Agronômica, v.47, n.3, p.509-515, 2016. DOI: http://dx.doi.org/10.5935/1806-6690.20160061

CAMPANHARO, M.; RODRIGUES, J.J.V.; LIRA JÚNIOR, E.; COSTA, M.C. Características físicas de diferentes substratos para produção de mudas de tomateiro. Revista Caatinga, v.19, n.2, p.140-145, 2006.

COLOMBO, R.C.; CRUZ, M.A.; CARVALHO, D.U.; HOSHINO, R.T.; ALVES, G.A.C.; FARIA, R.T. Adenium obesum as a new potted flower: growth management. Ornamental Horticulture, v.24, n.3, p. 197-205, 2018 a. DOI: https://doi.org/10.14295/oh.v24i3.1226 
COLOMBO, R.C.; FAVETTA, V.; SILVA, M.A.A.; FARIA, R.T. Substrates and irrigation levels for growing desert rose in pots. Ciência e Agrotecnologia, v.42, n.1, p.69-79, 2018b. DOI: http://dx.doi.org/10.1590/141370542018421002117

FERREIRA, D.F. Sisvar: a computer statistical analysis system. Ciência e Agrotecnologia, v.35, n.6, p.10391042, 2011. DOI: http://dx.doi.org/10.1590/S141370542011000600001

GOMES, J.M.; COUTO, L.; LEITE, H.G.; XAVIER, A.; GARCIA, S.L.R. Parâmetros morfológicos na avaliação da qualidade de mudas de Eucalyptus grandis. Revista Árvore, v.26, n.6, p.655-664, 2002. DOI: http://dx.doi. org/10.1590/S0100-67622002000600002

KLEIN, C.; KLEIN, V.A. Estratégias para potencializar a retenção e disponibilidade de água no solo. Revista do Centro de Ciências Naturais e Exatas, v.19, n.1, p.21-29, 2015.

MONTEIRONETO, J.L.L.; ARAÚJO, W.F.; VILARINHO, L.B.O.; SILVA, E.S.; ARAÚJO, W.B.L.; SAKAZAKI, R.T. Produção de mudas de pimentão (Capsicum annuum L.) em diferentes ambientes e substratos. Revista Brasileira de Ciências Agrárias (Agrária), v.11, n.4, p.289-297, 2016. DOI: http://dx.doi.org/10.5039/agraria.v11i4a5395

MONTEIRO NETO, J.L.L.; ARAÚJO, W.F.; CHAGAS, E.A.; SIQUEIRA, R.H.S.; OLIVEIRA, G.A.; ABANTORODRIGUEZ, C. Hydrogels in Brazilian Agriculture. RevistaAgro@mbiente On-line, v.11, n.4, p.347-360, 2017. DOI: http://dx.doi.org/10.18227/1982-8470ragro. v11i4.4130
MONTEIRO NETO, J.L.L.; ARAÚJO, W.F.; VILARINHO, L.B.O.; NUNES, T.K.; SILVA, E.S.; MAIA, S.S.; ALBUQUERQUE, J.A.A.; CHAGAS, E.A.; SIQUEIRA, R.H.S.; ABANTO-RODRIGUEZ, C. Produção de duas cultivares de tomates (Solanun licopersicum L.) em diferentes ambientes e substratos. Revista Acta Agronômica, v.67, n.2, p. 270-276, 2018. DOI: https://doi. org/10.15446/acag.v67n2.67943

RODRIGUES, E.T.; LEAL, P.AM.; COSTA, E.; PAULA, T.S.; GOMES, V.A. Produção de mudas de tomateiro em diferentes substratos e recipientes em ambiente protegido. Horticultura Brasileira, v.28, p.483-488, 2010. DOI: http://dx.doi.org/10.1590/S0102-05362010000400018

SANTOS, A.C.M.; RODRIGUES, L. U.; ANDRADE, C.A.O.; CARNEIRO, J.S.S.; SILVA, R. R. Ácidos húmicos e nitrogênio na produção de mudas de alface. Pesquisa Aplicada \& Agrotecnologia, v.11, n.1, p.69-77, 2018. DOI: $10.5935 /$ PAeT.V11.N1.08

SHIMADA, A.; KUBO, T.; TOMINAGA, S.; YAMAMOTO, M. Effect of Temperature on Photosynthesis Characteristics in the Passion Fruits 'Summer Queen' and 'Ruby Star'. The Horticulture Journal, v.86, n.2, p.194199, 2017. DOI: https://doi.org/10.2503/hortj.OKD-023

TAIZ, L.; ZEIGER, E. Fisiologia Vegetal, 5ed. Porto Alegre, Editora ArtMed, 2013. 954p.

TIAGO NETO, L.J.; RODRIGUES, O.D.; TSAI, H.M.; ESTEVAM, J.T.; PEREIRA, J.M.; SELEGUINI, A. Ocorrência de insetos fitófagos em Adenium obesum (Forssk.) Roem. \& Schult no estado de Goiás. Revista Agro@mbiente On-line, v.11, n.4, p.379-384, 2017. DOI: http://dx.doi.org/10.18227/1982-8470ragro.v11i4.4222 